\title{
Carbamate derivatives and sesquiterpenoids from the South China Sea gorgonian Melitodes squamata
}

\author{
Li-Si Huang $^{1}$, Fei He ${ }^{1}$, Hui Huang ${ }^{1,2}$, Xiao-Yong Zhang ${ }^{1}$ and Shu-Hua Qi ${ }^{*}{ }^{\circledR} \S$
}

\section{Full Research Paper}

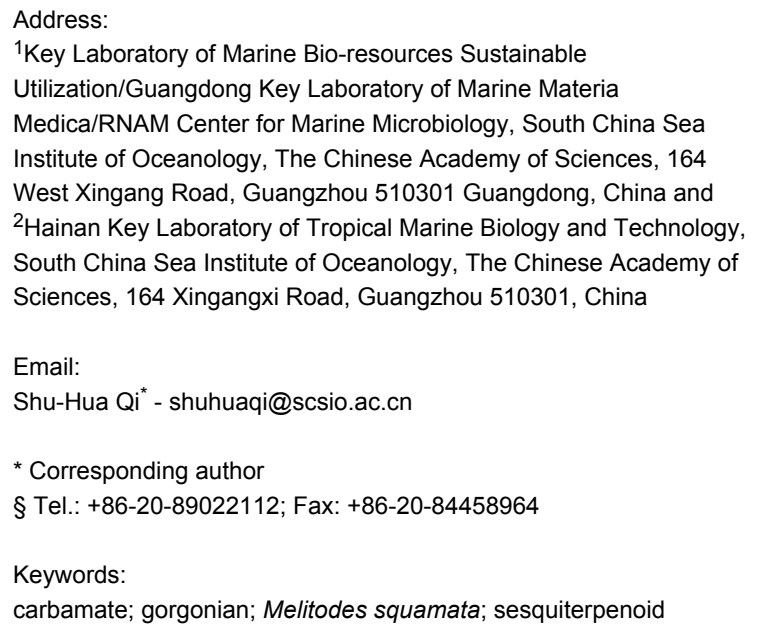

Beilstein J. Org. Chem. 2012, 8, 170-176. doi:10.3762/bjoc.8.18

Received: 05 August 2011

Accepted: 10 January 2012

Published: 31 January 2012

Associate Editor: D. Trauner

(C) 2012 Huang et al; licensee Beilstein-Institut. License and terms: see end of document.

\begin{abstract}
Five carbamate derivatives, obtucarbamates $\mathrm{C}$ and D (1, 2), dimethyl ((carbonylbis(azanediyl))bis(2-methyl-5,1-phenylene))dicarbamate (3), obtucarbamates A and B $(4,5)$, and four aromadendrane-type sesquiterpenoids, $(+)-4 \beta-N$-methenetauryl-10 3 -methoxy-

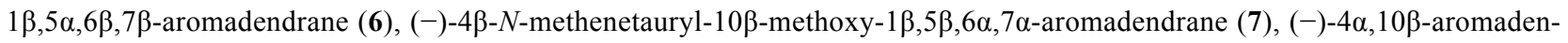
dranediol (8), (+)-4 $\beta, 10 \beta$-aromadendranediol (9) were obtained from the South China Sea gorgonian coral Melitodes squamata Nutting. Compounds 1, 2, 6, and 7 were new, and their structures were established by spectroscopic analyses. Compounds 6 and 7 contained a taurine group that was rarely found in marine natural compounds, and $\mathbf{7}$ showed moderate antibacterial activity. The possible biosynthesis routes of $\mathbf{1}-\mathbf{5}$ were conjectured.
\end{abstract}

\section{Introduction}

Gorgonians are recognized to mainly produce acetogenins, sesquiterpenoids, diterpenoids, prostanoids, and steroids [1,2]. However, nitrogen-containing compounds were relatively few obtained from gorgonians. Gorgonian Melitodes squamata Nutting belonging to Melithaea family is a kind of pharmaceutical coral that has the efficacy of relieving cough, bleeding, and diarrhea, soothing nerves, and calming scare, etc [3]. A previous study on the chemical constituents of Melithaea family gorgonians led to the isolation of four new steroids melithasterols A-D from Melithaea ocracea [4].

\section{Results and Discussion}

In order to further obtain new bioactive compounds from gorgonians, we studied the chemical constituents of the South China Sea gorgonian M. squamata, which led to the obtainment of five carbamate derivatives, obtucarbamates C and D $(\mathbf{1}, \mathbf{2})$, 
((carbonylbis(azanediyl))bis(2-methyl-5,1-phenylene))dicarbamate (3) [5], obtucarbamate A (4) [6], obtucarbamate B (5) [6], and four aromadendrane-type sesquiterpenoids, $(+)-4 \beta-N$ methenetauryl-10 $\beta$-methoxy- $1 \beta, 5 \alpha, 6 \beta, 7 \beta$-aromadendrane (6),

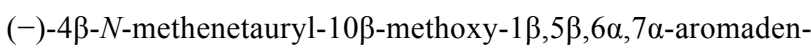

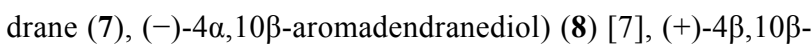
aromadendranediol) (9) [7] (Figure 1) from the $\mathrm{EtOH} / \mathrm{CH}_{2} \mathrm{Cl}_{2}$ extracts of M. squamata. Compounds 1, 2, 6, and 7 have not been previously reported. The cytotoxicity of $\mathbf{1 - 9}$ against human malignant melanoma A735 and cervical carcinoma HeLa cell lines, and the antibacterial activity of 1-5 and 7 towards bacteria Escherichia coli, Bacillus subtilis and Micrococcus luteus were evaluated. The possible biosynthesis routes of 1-5 were conjectured.

Compound 1 showed the same molecular formula of $\mathrm{C}_{19} \mathrm{H}_{22} \mathrm{~N}_{4} \mathrm{O}_{5}$ as 3 , which was determined by its HRMS-ESI $\left(\mathrm{m} / z\right.$ 409.1568 $\left.[\mathrm{M}+\mathrm{Na}]^{+}\right)$and NMR spectra. The ${ }^{1} \mathrm{H}$ NMR spectrum of 1 (Table 1) exhibited signals for three ABX system aromatic protons at $\delta_{\mathrm{H}} 7.50(\mathrm{~s}, 1 \mathrm{H}), 7.19(\mathrm{dd}, J=2.0,8.0 \mathrm{~Hz}$, $1 \mathrm{H}), 7.06(\mathrm{~d}, J=8.0 \mathrm{~Hz}, 1 \mathrm{H})$, three ABC system aromatic protons at $\delta_{\mathrm{H}} 7.57(\mathrm{~d}, J=8.0 \mathrm{~Hz}, 1 \mathrm{H}), 7.08(\mathrm{t}, J=8.0 \mathrm{~Hz}, 1 \mathrm{H})$, $6.99(\mathrm{~d}, J=8.0 \mathrm{~Hz}, 1 \mathrm{H})$, two methyl groups at $\delta_{\mathrm{H}} 2.12(\mathrm{~s}, 3 \mathrm{H})$, $2.07(\mathrm{~s}, 3 \mathrm{H})$, and two methoxy groups at $\delta_{\mathrm{H}} 3.63(\mathrm{~s}, 3 \mathrm{H}), 3.64$ (s, 3H). It also showed four $-\mathrm{NH}$ protons at $\delta_{\mathrm{H}} 8.90(\mathrm{~s}), 8.78$ (s) and $8.52(\mathrm{~s}, 2 \mathrm{H})$. The ${ }^{13} \mathrm{C}$ NMR and DEPT 135 spectral data (Table 1) showed the presences of 19 carbons, including three carbonyl carbons $\left(\delta_{\mathrm{C}} 154.5,154.6,152.7\right), 12$ aromatic carbons, two methyl carbons $\left(\delta_{\mathrm{C}} 16.9,12.4\right)$, and two methoxy carbons at $\delta_{\mathrm{C}}$ 51.5. The NMR data of $\mathbf{1}$ were very similar to those of compounds $3-5[5,6]$. Compound $\mathbf{3}$ is a symmetric urea derivative that was formed from the amidation of two molecules of 4 [6]. Comparison of the NMR data of $\mathbf{1}$ with 3-5 suggested that $\mathbf{1}$ was an asymmetric urea derivative that was formed from the amidation of $\mathbf{4}$ and $\mathbf{5}[5,6]$.

The suggestion was supported by the HMBC correlations (Figure 2). In the HMBC spectrum of 1, correlations of Me-7 (s, 2.12) with $\delta_{\mathrm{C}} 130.1(\mathrm{~d}, \mathrm{C}-5), 124.3(\mathrm{~s}, \mathrm{C}-6), 136.5$ (s, C-1) and Me-7' (s, 2.07) with $\delta_{\mathrm{C}} 124.0$ (s, C-2'), 137.1 (s, C-1'), 137.1 (s, C-3') indicate a methyl group attached at both C-6 and C-2'. The HMBC correlations of $\delta_{\mathrm{H}} 3.64(\mathrm{~s})$ with $\delta_{\mathrm{C}} 154.5(\mathrm{~s})$ and $\delta_{\mathrm{H}}$ $3.63(\mathrm{~s})$ with $\delta_{\mathrm{C}} 154.6(\mathrm{~s})$ revealed the presence of two -NHCOOMe groups. The HMBC correlations of $\delta_{\mathrm{H}} 8.78(\mathrm{NH})$ with $\delta_{\mathrm{C}} 124.3(\mathrm{C}-6), 114.0(\mathrm{C}-2), \delta_{\mathrm{H}} 8.90(\mathrm{NH})$ with $\delta_{\mathrm{C}} 124.0$ (C-2'), $119.2\left(\mathrm{C}^{\prime} 4^{\prime}\right)$, and $\delta_{\mathrm{H}} 8.52(2 \mathrm{NH})$ with $\delta_{\mathrm{C}} 114.0(\mathrm{C}-2)$,<smiles>COC(=O)Nc1ccc(NC(=O)Nc2[c]cccc2C(C)(C)C)cc1NC(=O)OC</smiles><smiles>COC(=O)Nc1ccc(C)c(NC(=O)OC)c1</smiles>

4

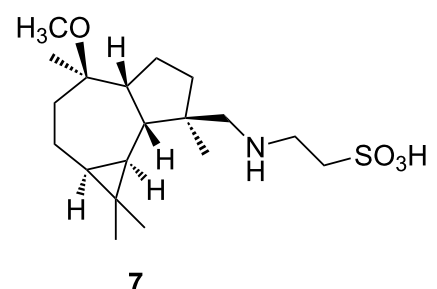

5<smiles>COC(=O)Nc1cc(NC(=O)Nc2ccc(C)c(NC(=O)Nc3ccc(C)c(NC(=O)Nc4ccc(C)c(NC(=O)OC)c4)c3)c2)ccc1C</smiles><smiles>COC(=O)Nc1cccc(NC(=O)OC)c1C</smiles>

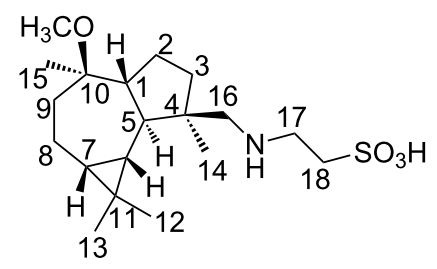

6

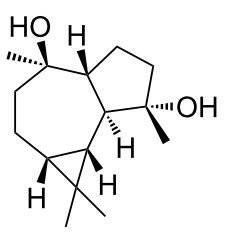

8

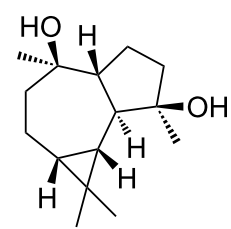

9

Figure 1: Structures of compounds 1-9. 


\begin{tabular}{|c|c|c|c|c|}
\hline \multirow[t]{2}{*}{ C } & \multicolumn{2}{|l|}{1} & \multicolumn{2}{|l|}{2} \\
\hline & $\delta_{\mathrm{H}}$ & $\delta_{C}$ & $\delta_{\mathrm{H}}$ & $\delta_{C}$ \\
\hline 1 & - & $136.5, \mathrm{C}$ & - & 136.3, C \\
\hline 2 & $7.50(\mathrm{~s})$ & $114.0, \mathrm{CH}$ & 7.54 (s) & 113.8, CH \\
\hline 3 & - & 138.3, C & - & $138.0, \mathrm{C}$ \\
\hline 4 & $7.19(\mathrm{dd}, 2.0,8.0)$ & $114.5, \mathrm{CH}$ & $7.19(\mathrm{br} \mathrm{d}, 8.0)$ & $114.0, \mathrm{CH}$ \\
\hline 5 & $7.06(\mathrm{~d}, 8.0)$ & $130.1, \mathrm{CH}$ & $7.06(\mathrm{~d}, 8.0)$ & $130.1, \mathrm{CH}$ \\
\hline 6 & - & $124.3, \mathrm{C}$ & - & $124.0, \mathrm{C}$ \\
\hline $1^{\prime}$ & - & 137.1, C & - & $137.5, \mathrm{C}$ \\
\hline $2^{\prime}$ & - & 124.0, C & $7.93(\mathrm{~s})$ & $111.4, \mathrm{CH}$ \\
\hline $3^{\prime}$ & - & 137.1, C & - & 137.0, C \\
\hline 4 & $7.57(\mathrm{~d}, 8.0)$ & $119.2, \mathrm{CH}$ & $7.04(\mathrm{~d}, 8.0)$ & $112.5, \mathrm{CH}$ \\
\hline $5^{\prime}$ & $7.08(t, 8.0)$ & $125.2, \mathrm{CH}$ & $7.07(\mathrm{~d}, 8.0)$ & $129.8, \mathrm{CH}$ \\
\hline $6^{\prime}$ & $6.99(\mathrm{~d}, 8.0)$ & $121.8, \mathrm{CH}$ & - & $121.7, \mathrm{C}$ \\
\hline $7-\mathrm{CH}_{3}$ & $2.12(\mathrm{~s})$ & $16.9, \mathrm{CH}_{3}$ & $2.12(\mathrm{~s})$ & 17.2, $\mathrm{CH}_{3}$ \\
\hline $7^{\prime}-\mathrm{CH}_{3}$ & $2.07(\mathrm{~s})$ & $12.4, \mathrm{CH}_{3}$ & $2.16(\mathrm{~s})$ & $16.9, \mathrm{CH}_{3}$ \\
\hline \multirow[t]{2}{*}{$\mathrm{OCH}_{3}$} & $3.64(\mathrm{~s})$ & $51.5, \mathrm{CH}_{3}$ & $3.64(\mathrm{~s})$ & $51.5, \mathrm{CH}_{3}$ \\
\hline & $3.63(\mathrm{~s})$ & $51.5, \mathrm{CH}_{3}$ & $3.63(\mathrm{~s})$ & $51.3, \mathrm{CH}_{3}$ \\
\hline$-\mathrm{NHCONH}-$ & $\begin{array}{l}8.78(\mathrm{~s}) \\
8.90(\mathrm{~s})\end{array}$ & 152.7, C & $\begin{array}{l}8.78(\mathrm{~s}) \\
9.46(\mathrm{~s})\end{array}$ & $152.5, \mathrm{C}$ \\
\hline$-\mathrm{NHCOO}-$ & $\begin{array}{l}8.52(\mathrm{~s}) \\
8.52(\mathrm{~s})\end{array}$ & $\begin{array}{l}\text { 154.5, C } \\
154.6, \mathrm{C}\end{array}$ & $\begin{array}{l}8.53(\mathrm{~s}) \\
8.53(\mathrm{~s})\end{array}$ & $\begin{array}{l}\text { 154.6, C } \\
154.2, \mathrm{C}\end{array}$ \\
\hline
\end{tabular}

114.5 (C-4), 121.8 (C-6'), 124.0 (C-2'), suggest that the four -NH groups are attached at $\mathrm{C}-1, \mathrm{C}-3, \mathrm{C}-1$ ', C-3' of two aromatic rings. Based on the above data analysis, the structure of 1 was elucidated to be as shown above and named as obtucarbamate $\mathrm{C}$.

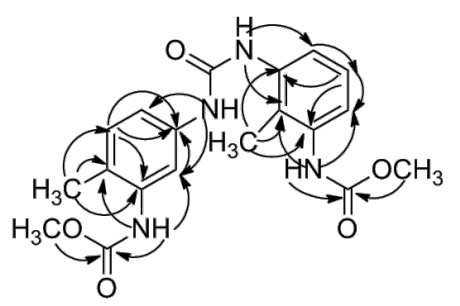

Figure 2: Key HMBC correlations of 1.

Compound 2 also exhibited the molecular formula of $\mathrm{C}_{19} \mathrm{H}_{22} \mathrm{~N}_{4} \mathrm{O}_{5}$ as deduced from NMR and HRMS-ESI $(\mathrm{m} / \mathrm{z}$ $409.1576[\mathrm{M}+\mathrm{Na}]^{+}$). The ${ }^{1} \mathrm{H}$ NMR data of 2 (Table 1 ) exhibited signals for two ABX aromatic systems, including six aromatic protons at $\delta_{\mathrm{H}} 7.54(\mathrm{~s}, 1 \mathrm{H}), 7.19(\mathrm{br} \mathrm{d}, J=8.0 \mathrm{~Hz}, 1 \mathrm{H})$, $7.06(\mathrm{~d}, J=8.0 \mathrm{~Hz}, 1 \mathrm{H}), 7.93(\mathrm{~s}, 1 \mathrm{H}), 7.07$ (d, $J=8.0 \mathrm{~Hz}, 1 \mathrm{H})$, $7.04(\mathrm{~d}, J=8.0 \mathrm{~Hz}, 1 \mathrm{H})$. The ${ }^{1} \mathrm{H}$ and ${ }^{13} \mathrm{C}$ NMR spectral data of 2 show similarities to those of $\mathbf{3}$ [5] (Table 1). Comparison of the NMR data of $\mathbf{2}$ and $\mathbf{3}$ suggests that $\mathbf{2}$ is an asymmetric urea derivative that was formed from the amidation of two mole- cules of $4[5,6]$, and the only difference between $\mathbf{2}$ and $\mathbf{3}$ is the amidation position of the two molecules of 4 . Based on the ${ }^{1} \mathrm{H}$ NMR, ${ }^{13} \mathrm{C}$ NMR HSQC, HMBC and ${ }^{1} \mathrm{H}-{ }^{1} \mathrm{H}$ COSY spectral data analysis, the structure of $\mathbf{2}$ was elucidated to be as shown above and named as obtucarbamate $\mathrm{D}$.

Urea derivatives are closely related in structure to carbamates. Urea is synthesized in the body of many organisms as part of the urea cycle, which is namely a cycle of biochemical reactions occurring in many animals that produces urea $\left(\left(\mathrm{NH}_{2}\right)_{2} \mathrm{CO}\right)$ from ammonia $\left(\mathrm{NH}_{3}\right)$. According to the reactions of the urea cycle [5], we made conjectures about the possible biosynthesis routes of compounds $\mathbf{2}-\mathbf{4}$ as shown (Figure 3). The possible biosynthesis routes to $\mathbf{1}, \mathbf{5}$ and $\mathbf{2 - 4}$ are essentially the same, except starting from 4-methylbenzene-1,3-diamine in place of 2-methybenzene-1,3-diamine. This is the first time that carbamate derivatives from gorgonians have been reported.

Compound 6 was assigned the molecular formula of $\mathrm{C}_{19} \mathrm{H}_{35} \mathrm{NSO}_{4}$ as deduced from NMR spectra and HRMS-ESI $\left(m / z 372.2170[\mathrm{M}-\mathrm{H}]^{-}\right)$. The ${ }^{1} \mathrm{H}$ NMR data (Table 2) indicate an aromadendrane skeleton with two cyclopropyl protons resonating at $\delta_{\mathrm{H}} 0.44(\mathrm{t}, J=10.0 \mathrm{~Hz}, 1 \mathrm{H})$ and 0.67 (ddd, $J=$ $6.5,10.0,11.5 \mathrm{~Hz}, 1 \mathrm{H})[7-11]$. The ${ }^{1} \mathrm{H}$ NMR spectrum also showed four singlet methyl groups $\left(\delta_{\mathrm{H}} 0.93,1.02,1.11,1.11\right)$ and a methoxy group $\left(\delta_{\mathrm{H}} 3.16\right)$. The ${ }^{13} \mathrm{C}$ NMR spectrum (Table 2) displayed 19 carbon signals, including five methyl 


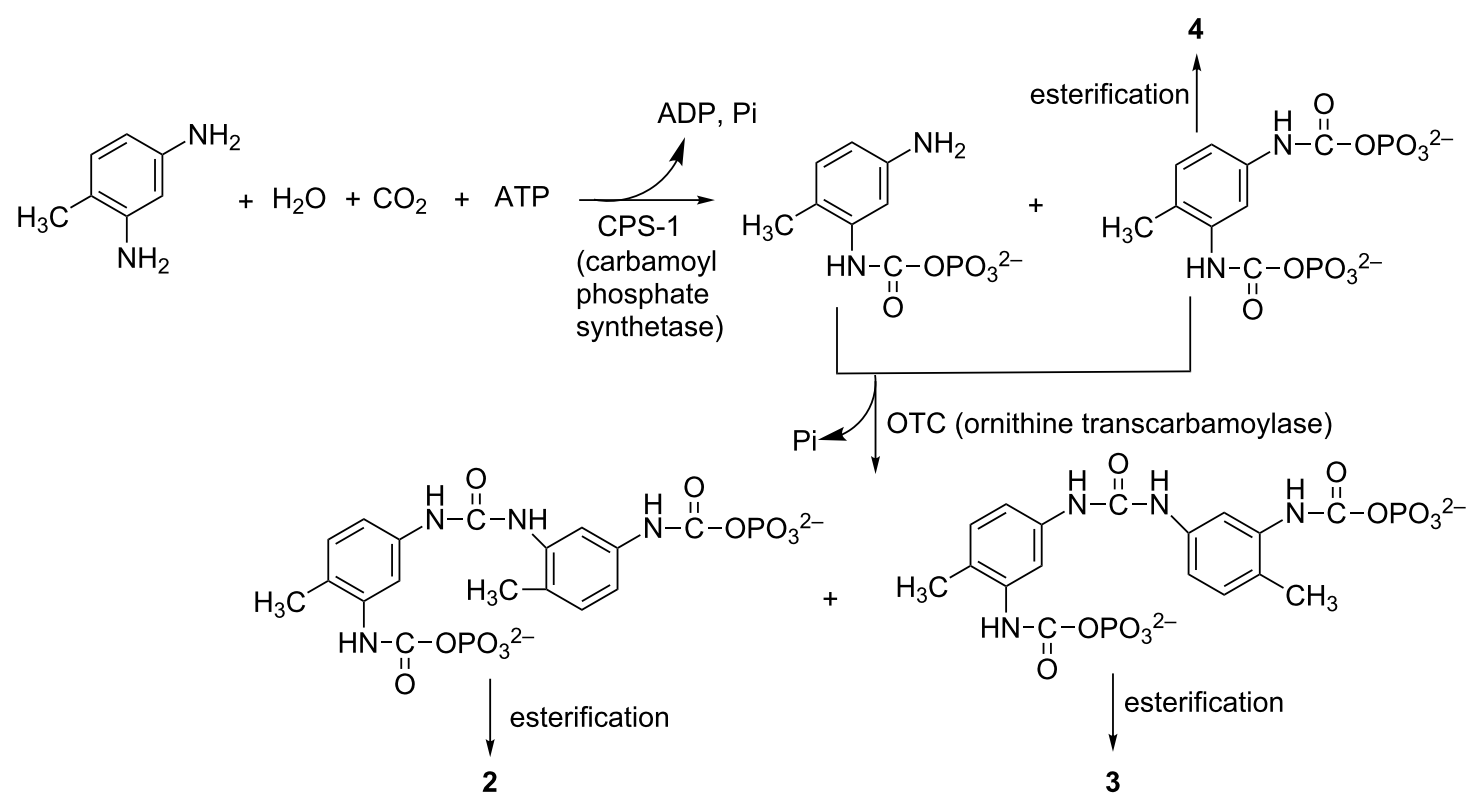

Figure 3: Possible biosynthesis routes of compounds 2-4.

Table 2: ${ }^{1} \mathrm{H}(500 \mathrm{MHz})$ and ${ }^{13} \mathrm{C}$ NMR $(125 \mathrm{MHz})$ data of 6 and 7 (in $\mathrm{CDCl}_{3}$, $\delta$ in ppm, $J$ in $\mathrm{Hz}$ ).

\begin{tabular}{|c|c|c|c|c|}
\hline \multirow[t]{2}{*}{ No. } & \multicolumn{2}{|l|}{6} & \multicolumn{2}{|l|}{7} \\
\hline & $\delta_{\mathrm{H}}$ & $\delta_{C}$ & $\delta_{\mathrm{H}}$ & $\delta_{C}$ \\
\hline 1 & $2.23(\mathrm{dd}, 8.0,17.0)$ & $50.1, \mathrm{CH}$ & $2.09(\mathrm{~m})$ & $52.2, \mathrm{CH}$ \\
\hline 2 & $1.73(\mathrm{~m})$ & $24.0, \mathrm{CH}_{2}$ & $1.67(\mathrm{~m})$ & $25.2, \mathrm{CH}_{2}$ \\
\hline 3 & $\begin{array}{l}1.37 \text { (t, 11.0), } \\
1.80 \text { (overlap) }\end{array}$ & $37.0, \mathrm{CH}_{2}$ & 1.61 (overlap) & $33.4, \mathrm{CH}_{2}$ \\
\hline 4 & - & $44.0, \mathrm{C}$ & - & $44.3, \mathrm{C}$ \\
\hline 5 & $0.98(\mathrm{brt}, 10.0)$ & $46.0, \mathrm{CH}$ & 1.72 (overlap) & $41.7, \mathrm{CH}$ \\
\hline 6 & $0.44(t, 10.0)$ & $25.6, \mathrm{CH}$ & $0.22(t, 9.5)$ & $24.3, \mathrm{CH}$ \\
\hline 7 & 0.67 (ddd, $6.5,10.0,11.5)$ & $26.6, \mathrm{CH}$ & $0.62(\mathrm{~m})$ & $28.7, \mathrm{CH}$ \\
\hline 8 & $\begin{array}{l}0.84 \text { (ddd, } 6.5,12.5,13.5) \\
1.87 \text { (ddd, } 6.5,11.5,13.5)\end{array}$ & $19.5, \mathrm{CH}_{2}$ & $\begin{array}{l}1.14(\mathrm{~m}) \\
1.59(\mathrm{~m})\end{array}$ & $18.2, \mathrm{CH}_{2}$ \\
\hline 9 & $\begin{array}{l}1.59(\mathrm{t}, 12.5) \\
1.67(\mathrm{dd}, 6.5,14.5)\end{array}$ & $37.2, \mathrm{CH}_{2}$ & $\begin{array}{l}1.48(\mathrm{t}, 12.0) \\
1.83(\mathrm{dd}, 6.5,14.5)\end{array}$ & $32.8, \mathrm{CH}_{2}$ \\
\hline 10 & - & $79.1, \mathrm{C}$ & - & $79.1, \mathrm{C}$ \\
\hline 11 & - & 19.6, C & - & 19.3, C \\
\hline 12 & $0.93(\mathrm{~s})$ & $28.7, \mathrm{CH}_{3}$ & $1.01(\mathrm{~s})$ & $28.3, \mathrm{CH}_{3}$ \\
\hline 13 & $1.02(\mathrm{~s})$ & $16.6, \mathrm{CH}_{3}$ & $0.99(\mathrm{~s})$ & $16.0, \mathrm{CH}_{3}$ \\
\hline 14 & $1.11(\mathrm{~s})$ & 17.6, $\mathrm{CH}_{3}$ & $1.20(\mathrm{~s})$ & $21.8, \mathrm{CH}_{3}$ \\
\hline 15 & $1.03(\mathrm{~s})$ & $17.8, \mathrm{CH}_{3}$ & $1.10(\mathrm{~s})$ & $24.4, \mathrm{CH}_{3}$ \\
\hline 16 & $\begin{array}{l}2.72(\mathrm{~d}, 12.0) \\
2.94(\mathrm{~d}, 12.0)\end{array}$ & $58.9, \mathrm{CH}_{2}$ & $\begin{array}{l}2.86(\mathrm{~d}, 12.5) \\
3.04(\mathrm{~d}, 12.5)\end{array}$ & $58.3, \mathrm{CH}_{2}$ \\
\hline 17 & $3.54(t, 5.0)$ & $45.8, \mathrm{CH}_{2}$ & 3.27 (br s) & $45.9, \mathrm{CH}_{2}$ \\
\hline 18 & $3.31(t, 5.0)$ & $45.9, \mathrm{CH}_{2}$ & 3.44 (br s), 3.53 (br s) & $45.7, \mathrm{CH}_{2}$ \\
\hline $\mathrm{OCH}_{3}$ & $3.16(\mathrm{~s})$ & $48.3, \mathrm{CH}_{3}$ & $3.10(\mathrm{~s})$ & $48.1, \mathrm{CH}_{3}$ \\
\hline
\end{tabular}

carbons $\left(\delta_{\mathrm{C}} 16.6,28.7,17.6,17.8,48.3\right)$, seven methylene carbons $\left(\delta_{\mathrm{C}} 24.0,37.0,19.5,37.2,45.8,45.9,58.9\right)$, four methine carbons $\left(\delta_{C} 50.1,46.0,25.6,26.6\right)$, and three quater- nary carbons $\left(\delta_{\mathrm{C}} 19.6,44.0,79.1\right)$. These NMR data (Table 2$)$ showed similarities to those of (-)- $4 \alpha, 10 \beta$-aromadendranediol (8), (+)-4 $\beta, 10 \beta$-aromadendranediol (9) and other analogues 
[7-11], which suggests that 6 is an aromadendrane-type sesquiterpenoid with a methoxy group and a side chain that contained three methylene carbons.

This suggestion was proved by the HMBC correlations (Figure 4). In the HMBC spectrum of $\mathbf{6}$, correlation of $\mathrm{MeO}-$ $\left(\delta_{\mathrm{H}} 3.16, \mathrm{~s}\right)$ with $\delta_{\mathrm{C}} 79.1$ indicates the methoxygenation of C-10. The HMBC correlations of $\mathrm{H}-16\left[\delta_{\mathrm{H}} 2.72(\mathrm{~d}, J=12 \mathrm{~Hz})\right.$, $2.94(\mathrm{~d}, J=12 \mathrm{~Hz})]$ with C-3 $\left(\delta_{\mathrm{C}} 37.0\right) / \mathrm{C}-4\left(\delta_{\mathrm{C}} 44.0\right) / \mathrm{C}-5\left(\delta_{\mathrm{C}}\right.$ $46.0) / \mathrm{Me}-14\left(\delta_{\mathrm{C}} 17.6\right)$ indicate that there is a side chain at $\mathrm{C}-4$ instead of a $-\mathrm{OH}$ group. The HMBC spectrum also shows correlations of $\mathrm{H}-16$ with $\mathrm{C}-17\left(\delta_{\mathrm{C}} 45.8\right)$ and $\mathrm{H}-17\left[\delta_{\mathrm{H}} 3.54(\mathrm{t}, J\right.$ $=5.0 \mathrm{~Hz})]$ with $\mathrm{C}-16\left(\delta_{\mathrm{C}} 45.8\right) / \mathrm{C}-18\left(\delta_{\mathrm{C}} 45.8\right)$. In the ${ }^{1} \mathrm{H}-{ }^{1} \mathrm{H}$ COSY spectrum (Figure 4), correlation of $\mathrm{H}-17$ with $\mathrm{H}-18\left[\delta_{\mathrm{H}} 3.31(\mathrm{t}, J=5.0 \mathrm{~Hz})\right]$ is observed. The above HMBC and ${ }^{1} \mathrm{H}-{ }^{1} \mathrm{H}$ COSY spectral data, combined with the molecular formula of $\mathrm{C}_{19} \mathrm{H}_{35} \mathrm{NSO}_{4}$, suggest the presence of a $-\mathrm{CH}_{2} \mathrm{NHCH}_{2} \mathrm{CH}_{2} \mathrm{SO}_{3} \mathrm{H}$ group. The suggestion was supported by the ${ }^{1} \mathrm{H}$ and ${ }^{13} \mathrm{C}$ NMR data comparison of the $-\mathrm{CH}_{2} \mathrm{NHCH}_{2} \mathrm{CH}_{2} \mathrm{SO}_{3} \mathrm{H}$ group in 6 with literature data $[12,13]$. The IR spectrum of $\mathbf{6}$ contains two strong bands at 1217 and $1041 \mathrm{~cm}^{-1}$, which supports the presence of a sulfonic acid group. The $-\mathrm{NHCH}_{2} \mathrm{CH}_{2} \mathrm{SO}_{3} \mathrm{H}$ group has rarely been found in marine natural compounds, such as $N$-methyltaurine, taurine, and spongidine D from sponges [12,13].

The relative stereochemistry of H-1, H-5, H-6, H-7, Me-14 and Me-15 in 6 was determined by NMR data comparison with literature data and NOESY spectral analysis. The chemical shifts $\left(\delta_{C} 16.6,28.7\right)$ of the methyl groups of Me-12 and Me-13 correlate well with those previously assigned to the corresponding methyl groups in 8, 9 and other analogues [7-11], which suggests the cis-orientation of the cyclopropane ring

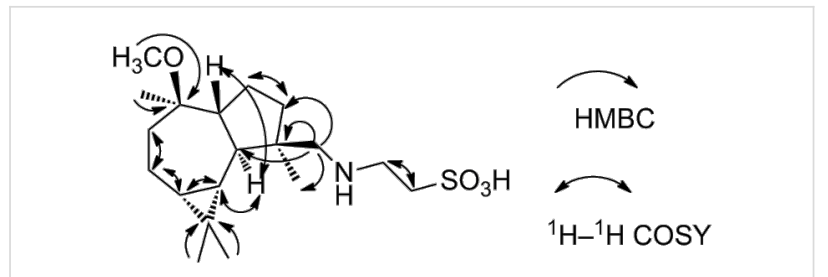

Figure 4: Key $\mathrm{HMBC}$ and ${ }^{1} \mathrm{H}-{ }^{1} \mathrm{H}$ COSY correlations of 6.

$[7,8]$. The coupling constants $(J=10.0 \mathrm{~Hz})$ between $\mathrm{H}-5$ and $\mathrm{H}-1 / \mathrm{H}-6$ indicate the trans-relationship of $\mathrm{H}-5$ with $\mathrm{H}-1$ and H-6. By comparison with the known chemical-shift data and shift parameters [7-11], the $\beta$-orientation of $\mathrm{H}-1, \mathrm{H}-6, \mathrm{H}-7$ and $\alpha$-orientation of $\mathrm{H}-5$ were assigned. In the seven-numbered ring, the methyl group $\mathrm{C}-15\left(\delta_{\mathrm{C}} 17.8\right)$ appears at a high field, reflecting that Me-15 is not in the same orientation as H-6 and H-7 [7]. In the NOESY spectrum, correlations of OMe-10 with $\mathrm{H}-1, \mathrm{H}-6, \mathrm{H}-7$ are observed (Figure 5), which suggest that OMe-10, H-1, H-6, H-7 are in $\beta$-orientation, meanwhile, the presence of correlations between $\mathrm{H}-5$ and Me-14/Me-13 indicates that $\mathrm{H}-5, \mathrm{Me}-14, \mathrm{Me}-13$ are in $\alpha$-orientation. Thus, the structure of 6 was elucidated to be as shown and named as $(+)-$ $4 \beta-N$-methenetauryl-10 $\beta$-methoxy- $1 \beta, 5 \alpha, 6 \beta, 7 \beta$-aromadendrane.

Compound 7 showed the same molecular formula of $\mathrm{C}_{19} \mathrm{H}_{35} \mathrm{NSO}_{4}$ as 6 on the basis of NMR spectra and HRMS-ESI $\left(m / z 372.2172[\mathrm{M}-\mathrm{H}]^{-}\right)$. The ${ }^{1} \mathrm{H}$ and ${ }^{13} \mathrm{C}$ NMR spectral data of 7 (Table 2) showed similarities to those of $\mathbf{6}$, except for some obvious differences in the chemical shift data of $\mathrm{H}-5$ (from $\delta_{\mathrm{H}}$ 0.98 to $\delta_{\mathrm{H}} 1.72$ ), C-3 (from $\delta_{\mathrm{C}} 37.0$ to $\delta_{\mathrm{C}} 33.4$ ), C-5 (from $\delta_{\mathrm{C}}$ 46.0 to $\delta_{\mathrm{C}} 41.7$ ), C-9 (from $\delta_{\mathrm{C}} 37.2$ to $\delta_{\mathrm{C}} 32.8$ ), and C-15 (from $\delta_{\mathrm{C}} 17.8$ to $\delta_{\mathrm{C}} 24.4$ ), which were caused by the stereochemistry change. In the ${ }^{1} \mathrm{H}-{ }^{1} \mathrm{H}$ COSY spectrum, no correlation between
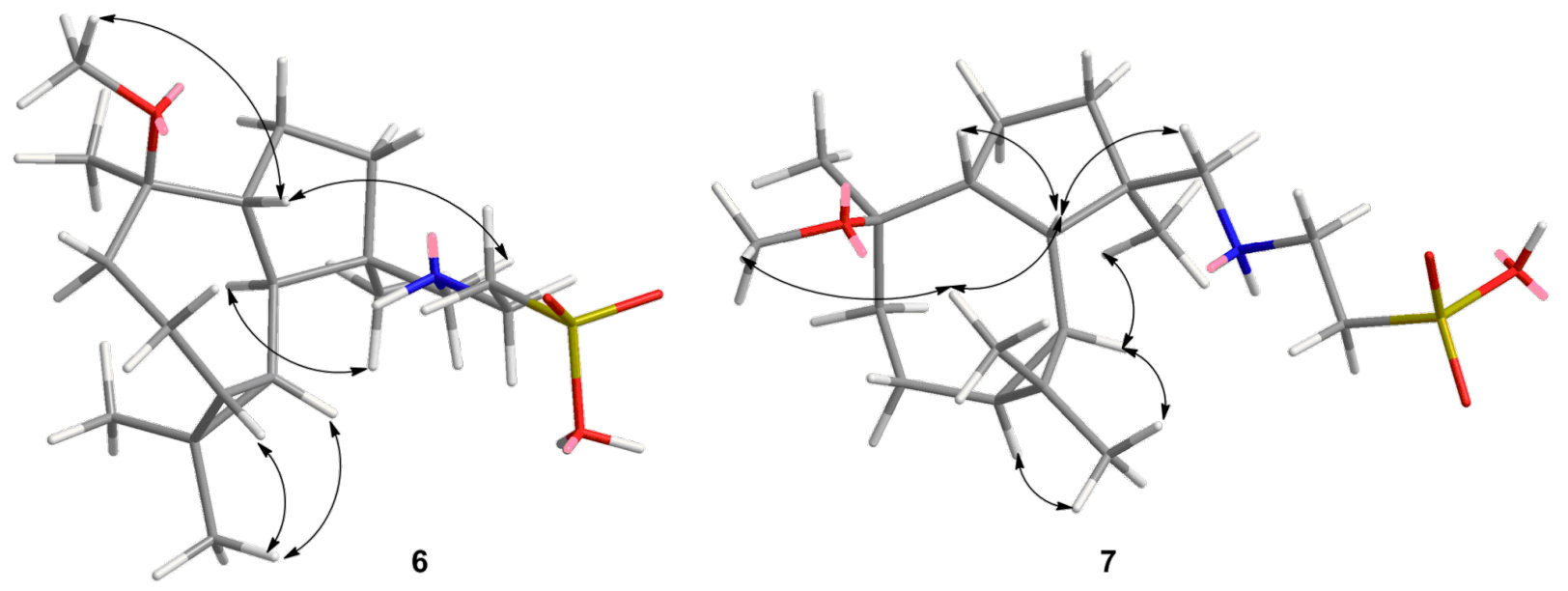

Figure 5: Key NOESY correlations of 6 and 7. 
H-1 and H-5 is observed, which suggests a small coupling constant and the cis relationship between H-1 and H-5. The coupling constant $(J=9.5 \mathrm{~Hz})$ between H-5 and H-6 indicates the trans-relationship of $\mathrm{H}-5$ with $\mathrm{H}-6$. In the NOESY spectrum, $\mathrm{H}-16$ shows correlations with $\mathrm{H}-1 / \mathrm{H}-5$, which suggests that $\mathrm{H}-16, \mathrm{H}-1$, and $\mathrm{H}-5$ are in $\beta$-orientation; meanwhile, correlations of $\mathrm{H}-6$ with $\mathrm{H}-7 / \mathrm{Me}-14 / \mathrm{Me}-13$ indicate that $\mathrm{H}-6, \mathrm{H}-7$, Me-14 and Me-13 are in $\alpha$-orientation. The chemical shift of Me-15 $\left(\delta_{C} 24.4\right)$ appears at a slightly lower field reflecting that Me-15 is at the same $\alpha$-orientation as H-6 and H-7 [7]. Thus, the structure of 7 was elucidated to be as shown and named as (-)-4 $\beta$ - $N$-methenetauryl-10 $\beta$-methoxy- $1 \beta, 5 \beta, 6 \alpha, 7 \alpha$-aromadendrane.

The cytotoxicity of compounds 1-9 against human malignant melanoma A735 and cervical carcinoma HeLa cell lines was evaluated by MTT assay. The results show that 1-9 does not exhibit cytotoxicity against A735 and HeLa cell lines with $\mathrm{IC}_{50}>$ $200 \mu \mathrm{g} / \mathrm{mL}$. Antibacterial activity of compounds $\mathbf{1}-\mathbf{5}$ at a concentration of $25 \mu \mathrm{g} /$ disc (diameter $6 \mathrm{~mm}$ ) was measured against bacteria Escherichia coli, Bacillus subtilis, and Micrococcus luteus strains by using standard disc-diffusion assay. The results show that $\mathbf{1}-\mathbf{5}$ exhibit no inhibitory effects towards all tested bacteria at $25 \mu \mathrm{g} / \mathrm{disc}, 7$ can inhibit the growth of $B$. subtilis and M. luteus with inhibition zones of $6.3 \mathrm{~mm}$ and 6.2 $\mathrm{mm}$, respectively, at $25 \mu \mathrm{g} / \mathrm{disc}$, while 7 has no effect towards E. coli at $25 \mu \mathrm{g} /$ disc. It was reported that taurine and its derivatives have a number of physiological functions, including interference with GABA and glycine receptors, antinociceptic effects, anticonvulsive actions, neuroprotective actions, etc. [14]. In this study, because of the limited quantity of compound, we did not further test the other bioactivities of $\mathbf{6}$ and 7.

\section{Experimental}

\section{General experimental procedures}

Optical rotations were measured with a Horiba SEAP-300 spectropolarimeter. UV spectra were measured with a Shimadzu double-beam 210A spectrophotometer in $\mathrm{MeOH}$ solution. ${ }^{1} \mathrm{H}$, ${ }^{13} \mathrm{C}$ NMR and 2D NMR spectra were recorded on a Bruker AV-500 MHz NMR spectrometer with TMS as internal standard. MS spectral data were obtained on an LCQDECA XP HPLC/MSn spectrometer for ESIMS. Silica gel (200-300 mesh) for column chromatography and $\mathrm{GF}_{254}$ for TLC were obtained from the Qindao Marine Chemical Factory, Qindao, People's Republic of China.

\section{Animal material}

The South China Sea gorgonian coral Melitodes squamata Nutting was collected in Sanya, Hainan province, China in July 2008 and identified by Prof. Huang H., the South China Sea Institute of Oceanology, Academia Sinica. A voucher specimen
(No. 0802) was deposited in the South China Sea Institute of Oceanology, Academia Sinica, Guangzhou, China.

\section{Extraction and isolation}

The frozen specimen of the South China Sea gorgonian coral $M$. squamata (20 kg, wet weight) was extracted with $\mathrm{EtOH} / \mathrm{CH}_{2} \mathrm{Cl}_{2}$ $(2: 1)$ three times at room temperature and the solvent was evaporated in vacuo. The residue was partitioned in $\mathrm{H}_{2} \mathrm{O}$ and extracted with EtOAc and $n$ - BuOH three times each. The extracts of each respective solvent were combined. The EtOAc and $n-\mathrm{BuOH}$ extracts were concentrated in vacuo to afford $35.17 \mathrm{~g}$ and $16.85 \mathrm{~g}$ of residue, respectively. The EtOAc extract was subjected to silica-gel column chromatography (column A), eluted with $\mathrm{CHCl}_{3} / \mathrm{MeOH}$ (from 1:10 to 0:10). By combining the fractions with TLC $\left(\mathrm{GF}_{254}\right)$ monitoring, 17 fractions were obtained. Fraction A-5 was applied to a Sephadex LH-20 column (column B), eluted with $\mathrm{CHCl}_{3} / \mathrm{MeOH}(1: 1)$, to obtain four fractions. Fraction B-4 was further purified by HPLC $\left(\mathrm{MeOH} / \mathrm{H}_{2} \mathrm{O} 45: 100\right)$ to yield $1\left(1.8 \mathrm{mg}, t_{\mathrm{R}}=23.5 \mathrm{~min}\right), 2$ $\left(1.8 \mathrm{mg}, t_{\mathrm{R}}=41.2 \mathrm{~min}\right), \mathbf{3}\left(2.8 \mathrm{mg}, t_{\mathrm{R}}=38.2 \mathrm{~min}\right), 4\left(2.7 \mathrm{mg}, t_{\mathrm{R}}\right.$ $=13.8 \mathrm{~min})$ and $\mathbf{5}\left(1.8 \mathrm{mg}, t_{\mathrm{R}}=9.0 \mathrm{~min}\right)$, separately. Fraction B-3 was further purified by RP-18 reverse-phase silica-gel column chromatography (column C), eluted with $\mathrm{MeOH} / \mathrm{H}_{2} \mathrm{O}$ (30:100), to yield $8(14.8 \mathrm{mg})$ and $9(9.5 \mathrm{mg})$. Fraction A-11 was separated by a Sephadex LH-20 column (column D), eluted with $\mathrm{CHCl}_{3} / \mathrm{MeOH}(1: 1)$ to give five fractions. Fraction D-2 was subjected to silica-gel column chromatography (column E), eluted with $\mathrm{CHCl}_{3} / \mathrm{MeOH}(10: 1)$, to yield 6 (4.2 mg) and three other fractions. Fraction E-2 was furthered purified by a Sephadex LH-20 column $\left(\mathrm{MeOH} / \mathrm{H}_{2} \mathrm{O} 95: 5\right)$ to yield 7 (4.8 mg).

Obtucarbamate C (1): White powder; UV (MeOH): 258, 216 $\mathrm{nm} ;{ }^{1} \mathrm{H}$ and ${ }^{13} \mathrm{C}$ NMR data, see Table $1 ;(+)$-ESIMS $(\mathrm{m} / \mathrm{z})$ : $409.0[\mathrm{M}+\mathrm{Na}]^{+}, 795.0[2 \mathrm{M}+\mathrm{Na}]^{+}$; HRMS-ESI $(\mathrm{m} / \mathrm{z}):[\mathrm{M}+$ $\mathrm{Na}]^{+}$calcd for $\mathrm{C}_{19} \mathrm{H}_{23} \mathrm{~N}_{4} \mathrm{O}_{5} \mathrm{Na}, 409.1590$; found, 409.1568 .

Obtucarbamate D (2): White powder; UV (MeOH): 258, 216 $\mathrm{nm} ;{ }^{1} \mathrm{H}$ and ${ }^{13} \mathrm{C}$ NMR data, see Table 1; (+)-ESIMS $(\mathrm{m} / \mathrm{z})$ : $409.1[\mathrm{M}+\mathrm{Na}]^{+}, 795.3[2 \mathrm{M}+\mathrm{Na}]^{+}$; HRMS-ESI $(\mathrm{m} / \mathrm{z}):[\mathrm{M}+$ $\mathrm{Na}]^{+}$calcd for $\mathrm{C}_{19} \mathrm{H}_{23} \mathrm{~N}_{4} \mathrm{O}_{5} \mathrm{Na}, 409.1590$; found, 409.1576 .

$(+)-4 \beta-N$-methenetauryl-10 $\beta$-methoxy-1 $1,5 \alpha, 6 \beta, 7 \beta-$ aromadendrane (6): White powder; $[\alpha]_{\mathrm{D}}{ }^{20}+26.4^{\circ}$ (c 0.28 , $\mathrm{MeOH}) ;{ }^{1} \mathrm{H}$ and ${ }^{13} \mathrm{C}$ NMR data, see Table 2; $(-)$-ESIMS $(\mathrm{m} / \mathrm{z})$ : $372.1[\mathrm{M}-\mathrm{H}]^{-}, 745.4[2 \mathrm{M}-\mathrm{H}]^{-}$; HRMS-ESI $(\mathrm{m} / \mathrm{z})$ : $[\mathrm{M}-\mathrm{H}]^{-}$ calcd for $\mathrm{C}_{19} \mathrm{H}_{34} \mathrm{NSO}_{4}, 372.2209$; found, 372.2170.

$(-)-4 \beta-N$-methenetauryl-10 $\beta$-methoxy-1 $\beta, 5 \beta, 6 \alpha, 7 \alpha-$ aromadendrane (7): White powder; $[\alpha]_{\mathrm{D}}{ }^{20}-7.5^{\circ}$ (c 0.48 , $\mathrm{MeOH}) ;{ }^{1} \mathrm{H}$ and ${ }^{13} \mathrm{C}$ NMR data, see Table $2 ;(-)$-ESIMS $(\mathrm{m} / \mathrm{z})$ : 
$372.2[\mathrm{M}-\mathrm{H}]^{-}, 745.4[2 \mathrm{M}-\mathrm{H}]^{-}$; HRMS-ESI $(\mathrm{m} / \mathrm{z})$ : $[\mathrm{M}-\mathrm{H}]^{-}$ calcd for $\mathrm{C}_{19} \mathrm{H}_{34} \mathrm{NSO}_{4}, 372.2209$; found, 372.2172.

\section{Acknowledgements}

The authors are grateful to the National Science Foundation of China (grant 20872151), the research supported by the CAS/ SAFEA International Partnership Program for Creative Research Teams (grant KZCX2-YW-T001), the National Basic Research Program of China (grant 2010CB8338-00-G), the National Science Foundation of China (grant 40976090 and 40910093), the Knowledge Innovation Program of Chinese Academy of Science (grant KSCX2-EW-G-12B), and the Hi-tech Research and Development Program of China (grant SQ2007AA09Z409) for financial support.

\section{References}

1. Coll, J. C. Chem. Rev. 1992, 92, 613-631. doi:10.1021/cr00012a006

2. Rodríguez, A. D. Tetrahedron 1995, 51, 4571-4618. doi:10.1016/0040-4020(95)00216-U

3. Shao, C. L.; Fu, X. M.; Wang, C. Y.; Han, L.; Liu, X.; Fang, Y. C.; Li, G. Q.; Zeng, X. Q.; Liu, G. X.; Guan, H. S. Period. Ocean Univ. China 2009, 39, 691-698.

4. Kobayashi, M.; Kanda, F. J. Chem. Soc., Perkin Trans. 1 1991, 1177-1179. doi:10.1039/P19910001177

5. Brown, G. W.; Cohen, P. P. Biochem. J. 1960, 75, 82-91.

6. Kuo, Y. H.; Jou, M. H. Chem. Express 1990, 5, 909-912.

7. Goldsby, G.; Burke, B. A. Phytochemistry 1987, 26, 1059-1063. doi:10.1016/S0031-9422(00)82350-X

8. Bohlmann, F.; Grenz, M.; Jakupovic, J.; King, R. M.; Robinson, H. Phytochemistry 1983, 22, 1213-1218. doi:10.1016/0031-9422(83)80224-6

9. Beechan, C. M.; Djerassi, C.; Eggert, H. Tetrahedron 1978, 34, 2503-2508. doi:10.1016/0040-4020(78)88378-1

10. Jizba, J.; Laudová, V.; Samek, Z.; Ubik, K.; Novotny, L. Collect. Czech. Chem. Commun. 1981, 46, 1048-1053. doi:10.1135/cccc19811048

11. Liu, H.-J.; Wua, C.-L.; Becker, H.; Zapp, J. Phytochemistry 2000, 53, 845-849. doi:10.1016/S0031-9422(99)00609-3

12. De Marino, S.; Iorizzi, M.; Zollo, F.; Debitus, C.; Menou, J.-L.; Ospina, L. F.; Alcaraz, M. J.; Payá, M. J. Nat. Prod. 2000, 63, 322-326. doi:10.1021/np990374+

13. Xynas, R.; Capon, R. J. Aust. J. Chem. 1989, 42, 1427-1433. doi:10.1071/CH9891427

14. Simo, S.; Oja, P. S. Proc. West. Pharmacol. Soc. 2007, 50, 8-15.

\section{License and Terms}

This is an Open Access article under the terms of the Creative Commons Attribution License

(http://creativecommons.org/licenses/by/2.0), which permits unrestricted use, distribution, and reproduction in any medium, provided the original work is properly cited.

The license is subject to the Beilstein Journal of Organic Chemistry terms and conditions:

(http://www.beilstein-journals.org/bjoc)

The definitive version of this article is the electronic one which can be found at:

doi:10.3762/bjoc. 8.18 